\title{
The Self-Represented Child in School Discipline under Ontario's Education Act
}

\author{
Jean-Frédéric Hübsch \\ Interdisciplinary Research Laboratory on the Rights of the Child \\ Faculty of Law - Civil Law Section \\ University of Ottawa, Ottawa, Canada
}

Abstract

In Ontario, students facing school discipline are not parties to their own suspension and expulsion proceedings. As in other areas of law, children in education law are treated as not having sufficient capacity to advance their own interests and must rely on adults to do so on their behalf. This barrier to direct participation in proceedings that affect them runs contrary to children's participation rights under the United Nations Convention on the Rights of the Child and to general principles of fairness. For children who are responsible for their own education, the inability to independently challenge school authorities with respect to school discipline undermines their education and their dignity. School discipline processes should be designed to respect children as individual rights holders.

Keywords: school discipline, participation, child rights, capacity, autonomy, access to justice 


\section{The Self-Represented Child in School Discipline under Ontario's Education Act}

The United Nations Convention on the Rights of the Child (1989, hereafter, the Convention) was ratified by Canada on December 13, 1991. Articles 28 and 29 of the Convention recognize children's right to education. Education is to be directed to, among other matters, the "development of respect for human rights and fundamental freedoms" (Article 29(1)(b)) and the "preparation of the child for responsible life in a free society" (Article 29(1)(d)). The Convention also recognizes the right of children to express their views and have these views "given due weight in accordance with the age and maturity of the child," in particular by being given the opportunity to be heard directly or through a representative in "any judicial or administrative proceedings affecting the child ... in a manner consistent with the procedural rules of national law" (Article 12).

Canada lags behind in terms of implementation of the Convention (Paré, 2017), including in education (Covell, 2020; Covell, Howe, \& McGillivray, 2017). The lack of implementation in Canadian education systems is attributed partially to Canada's federal structure. Under Canada's constitution, the provinces are responsible for education. For example, the Province of Ontario has four types of school boards split along linguistic - i.e., English and French - and confessional - i.e., nonconfessional and Catholic - lines. The result is a total of 72 school boards across the province, from urban boards with large student populations, to boards serving immense geographic areas with small student populations. School board jurisdictions may overlap where two or more school board types have a presence in the same area. In addition, Ontario has a handful of remote or isolated school authorities, hospital-based schools, and schools operated directly by the province for children who are deaf, blind, and deafblind and for children with severe disabilities. The Government of Ontario, alongside the federal government, has also entered into agreements with Indigenous nations to develop their own Indigenous-led education systems (Government of Ontario, 2017). The result is a patchwork of education systems, not only in Canada as a whole but also within a single province. 
In Ontario, all publicly funded school boards and authorities, except those run directly by Indigenous communities, are subject to the requirements of Ontario's Education Act. While there has been some movement in Canadian law toward greater direct participation by children in matters that affect them, Ontario's Education Act still proscribes children's participation. In the school discipline context, only parents or guardians can challenge suspensions or expulsions unless a school board's policy explicitly states that a child can do so (Education Act, ss. 309, 311.3). While parents and guardians may choose to exercise review or appeal rights, some do not (Hussain, 2015; Milne \& Aurini, 2015), leaving a child without any assurance of the fairness of the disciplinary processes that directly affect them. Moreover, even if a school board's policy provides that children can challenge suspensions or expulsions at the local level, once an expulsion appeal is made, it is heard by a provincial tribunal that follows only the letter of the Education Act regardless of local policies (Scott, 2019). As such, only a parent or guardian can appeal an expulsion; a child cannot.

The failure to fully implement the Convention and to systematically recognize children as individual rights holders means children in Ontario who face suspension or expulsion from school have few guarantees of participation under the Education Act (Raby, 2012). Due to the continued influence of parental rights discourse (Covell, 2020; Lundy \& O'Lynn, 2019; Daly, 2018; Covell, Howe, \& McGillivray, 2017; Appel, 2013; McGillivray, 2011), the legal regime fails to live up to the Convention's standard that "school discipline [be] administered in a manner consistent with the child's human dignity" (Convention, Article 28(2)), which includes giving children a voice in school (Committee on the Rights of the Child, 2009). I propose that school suspension and expulsion processes in Ontario be redesigned to meet the needs of the children they affect. In particular, these processes need to treat children as individual rights-holders and account for the possibility that children may not have an adult in their lives who will engage with and challenge school authorities on their behalf.

I have chosen Ontario for this project partially out of convenience, given my experience working in education law in Ontario. However, Ontario is Canada's most populous province, meaning that education decisions made in Ontario affect about a third of all children in Canada (Statistics Canada, 2016). Moreover, Ontario in the late 2000s - well after Canada ratified the Convention - enacted new approaches to school discipline that were intended to better respect children's rights under Ontario's Human Rights Code by moving away from "zero tolerance" to 
a "progressive discipline" model. I seek to contribute to the discussion of the ongoing impact of these changes by applying a children's rights lens to the progressive discipline model as it has been experienced by children. I will begin by briefly unpacking the extent of Canada's recognition of children's rights in law. I will then assess the school suspension and expulsion processes as set out in Ontario's Education Act and push back against the law's reliance on parents to advocate for their children in school discipline, drawing on existing research about children's views of school discipline in Ontario to demonstrate that children have the capacity and the desire to participate directly in school discipline proceedings. I will conclude with a discussion of the basic requirements for promoting greater access to justice for children in school discipline in Ontario.

Disciplinary measures short of suspension and expulsion are outside the scope of this discussion, as are nondisciplinary exclusionary mechanisms such as "refusal to admit" (Reid, 2017). These less formal practices, which are not spelled out in any detail in the law or in provincial guidance documents, may vary greatly between local school boards. Further study in this area would help to provide a more complete picture of students' participation in school discipline matters. Suspensions and expulsions are merely a potential starting point for implementing the Convention in Ontario education law.

If we are to convince the courts and the legislatures that children in school deserve to be treated as individual rights-holders, we need to show that relying on parental rights alone is problematic and that children are capable of understanding and exercising their rights. We also need to provide potential ways forward for ensuring greater access to justice for children on their own terms. In so doing, we can lay the groundwork for more systematic implementation of the Convention in education systems, respecting not only the child's right to participate but also the child's right to learn about and exercise their rights generally.

\section{Children's Rights and Education in Canada}

The United Nations Committee on the Rights of the Child in its General Comment No. 1 (2001) states at paragraph 8

Children do not lose their human rights by virtue of passing through the school gates.

Thus, for example, education must be provided in a way that respects the inherent dignity of the child and enables the child to express his or her views freely in accordance with article 12 (1) and to participate in school life. Education must also be provided in a way 
that respects the strict limits on discipline reflected in article 28 (2) and promotes nonviolence in school.

The committee's general comment on the right to be heard (2009) speaks to administrative decision-making, including in schools. It notes that "the right to be heard applies both to proceedings which are initiated by the child, such as complaints against ill-treatment and appeals against school exclusion, as well as to those initiated by others which affect the child, such as parental separation or adoption" (para 33). Verheyde (2006) in her detailed examination of the committee's interpretation of the right to education argues that the content of the right to education as set out in Article 29 provides "a more balanced approach to education as belonging to children as well as to parents, especially with regard to some traditional parental rights in education” (p. 58). This echoes Mason \& Cohen's (2001) view that the participation rights set out in Article 12 are a way to "balance the rights of the child with the duties of parents and others responsible for the child's survival, development and protection.” (p. 15)

A further element of the Convention that is relevant to the education context is the best interests of the child. Article 3 requires that decisions relating to children and youth should be made in their best interests. The participation of children is an integral part of determining the best interests of the child (Covell, Howe, \& Blokhuis, 2018) and is intended to inform adult decision-making about children by recognizing children as people with their own needs (Mason \& Cohen, 2001). In Baker v. Canada (Minister of Citizenship and Immigration) (1999, hereafter Baker), a seminal case from the Supreme Court of Canada, the court noted that even though the Convention does not have direct effect in Canada as it has not been incorporated into domestic law, "[t]he values and principles of the Convention recognize the importance of being attentive to the rights and best interests of children when decisions are made that relate to and affect their future" (para 71). In education specifically, the Supreme Court of Canada's decision in Eaton $v$. Brant County Board of Education, stands for the proposition that "for older children who are capable of communicating, their views and wishes will 'play an important role' in the determination of what is in their best interests" (Aiken \& Scott, 2000, p. 234). As a result of Eaton, school board officials are required to assess the educational needs of a child with severe disabilities through the lens of the best interests of the child, with the participation of the child. While these cases are both considered high-water marks in terms of children's rights in Canada, their promise remains unfulfilled (McGillivray, 2011). Even though the recently enacted 
Ontario's Child, Youth and Family Services Act, 2017 recognizes the necessary connection between participation and best interests, and explicitly includes participatory rights for children who interact with child-welfare authorities, in most contexts, such as family law and immigration law, children's voices continue to be mediated by adults (Bala \& Houston, 2015).

Another important aspect to consider when discussing the law as it applies to state administrative bodies, including schools, is procedural fairness. In Baker, the Supreme Court of Canada emphasized that the purpose of the duty of procedural fairness is

to ensure that the administrative decisions are made using a fair and open procedure, appropriate to the decision being made and its statutory, institutional, and social context, with an opportunity for those affected by the decision to put forward their views and evidence fully and have them considered by the decision-maker. (para 22)

Building on Baker and focusing on a Supreme Court of Canada case called Doré about the application of the Canadian constitution's Charter of Rights and Freedoms in administrative decision-making, Cameron \& Daly (2013), both legal scholars at a Canadian university, argue that the wide discretion that educators enjoy as a result of school board policies, set in the larger framework of educational laws and regulations, can be used by educators to promote fairness and equality in school decision-making, in accordance with the values underlying the Canadian Charter. However, studies asking students from Ontario schools about their perspectives on school discipline demonstrate that this potential remains unfulfilled (Hussain, 2015; Raby, 2012; Mosher, 2008). These studies, which are discussed in greater detail below, consistently found that students who have experienced school discipline find the decision-making processes opaque and arbitrary. Moreover, studies that asked teachers in an Ontario school board about their experiences with student discipline (Milne \& Aurini, 2015; Raby, 2012) found that teachers themselves struggle when handling disciplinary matters due to lack of clear guidelines and uncertainty about the application of relevant legal principles. Despite the apparent possibilities for greater fairness in schools through existing Canadian rights instruments, procedural fairness remains elusive for children in schools.

The final legal consideration I will mention, which is connected to procedural fairness, is the idea of standing. Standing is the ability for a person to participate in proceedings that affect them. For an adult, their capacity to come before a decision-maker and plead their case is presumed. Children, however, do not always benefit from such a presumption. According to the 
Supreme Court of Canada, "the heart of [procedural fairness] is whether, considering all the circumstances, those whose interests were affected had a meaningful opportunity to present their case fully and fairly" (Baker, para 30). What it means to meaningfully participate can differ depending on the context, but absent specific language in the relevant legislation (Justice for Children and Youth, 2013), the result in matters that affect children is a "presumption that [parents] are actually representing their child" (Paré, 2015, p. 48). Children must therefore rely on adults to represent them, even if they are able and willing to represent themselves.

Bala \& Houston (2015) discuss areas in which such rights-granting language exists for children, such as a child consenting to health care or when facing the criminal justice system. In Ontario, children have a right as a party to appeal a determination with respect to their capacity to consent (Justice for Children and Youth, 2013). In addition, a publicly funded Children's Lawyer may be appointed in certain circumstances (Zuker \& Kirwin, 2015), and under the Child, Youth and Family Service Act, 2017 children in care can initiate their own complaints with respect to violations of their rights by service providers, and those who are at least 12 years old have the ability to challenge placement and secure treatment decisions directly to the provincial Child and Family Services Review Board. More generally, courts and tribunals may grant standing to a child, though the child generally still needs to be represented by an adult (Grover, 2008). These examples show that children can be and are included in certain types of legal proceedings. These are the exceptions, however, and they apply only in very specific circumstances. In terms of legal standing generally, children's interests are effectively subsumed into those of their parents (Aiken \& Scott, 2000; Appell, 2013; Godwin, 2015). This state of affairs has been understood to be in the child's best interest due to concerns about children's development and capacity (Appell, 2013). However, "[t]elling children that they are incompetent and must find an adult to knock on the courthouse door for them is simply putting another obstacle in the way of justice" (Pitts, 2005, p. 348, quoted in Grover, 2008, p. xv). The law's treatment of all children as equally vulnerable and immature, moreover, is a sweeping generalization (Daly, 2018) that fails to appreciate that each child has their own rights independent from those of adults (Grover, 2008; Aiken \& Scott, 2000).

Despite Canada's ratification of the Convention and its constitutionally entrenched Charter of Rights and Freedoms, the courts have not recognized children as individual rightsholders (Covell, 2020; Paré, 2017; McGillivray, 2011; Sitch \& McCoubrey, 2001-2002). The 
school discipline context in Ontario provides a stark example of this failure. I now turn to a brief review of the Education Act's discipline provisions, which will inform the discussion thereafter about ways to better respect children as individual rights-holders in school discipline.

\section{School Discipline Under Ontario's Education Act}

In the 1990s, Ontario school boards had their own policies and procedures for discipline, leading to inconsistent processes across the province. The government of the day eventually introduced the Safe Schools Act, 2000, which created categories of mandatory disciplinary measures. However, not long after the adoption of this new legislation, the Ontario Human Rights Commission began receiving complaints that the relevant provisions of the Education Act and related school board policies were disproportionately affecting racialized students and students with disabilities (Hill, 2013). Two settlements resulted from these complaints - one with the Ministry of Education and the other with the Toronto District School Board - that in 2007 eventually led to the introduction of amendments to the Education Act to, among other matters, enshrine procedures in legislation to promote fairer decision-making around discipline. This included increased discretion for administrators when determining appropriate discipline, emphasis on prevention and early intervention as well as restorative and rehabilitative principles, and the development of appeal rights for suspension in addition to expulsion. The local implementation of these changes was supported through several memoranda issued by the Ministry of Education. Further legislation in 2012 amended the Education Act to explicitly include obligations on school boards with respect to addressing specifically bullying, harassment, and discrimination (Hill, 2013).

The current framework for student discipline in Ontario is set out in part XIII of the Education Act. In 2012, the Ministry of Education issued Policy/Program Memorandum No. 145 - Progressive Discipline and Promoting Positive Student Behaviour that speaks of "combin[ing] prevention and intervention strategies and discipline with opportunities for students to continue their education" in order to create a "positive school climate" through "an effective continuum" of "developmentally and socio-emotionally appropriate" strategies (pp. 1-3). In accordance with the Act and ministry guidance, school boards are empowered to set guidelines for the imposition of disciplinary measures in their own policies and procedures to help staff respond appropriately and consistently to incidents of misconduct. They are also required to develop school board and local codes of conduct based on the provincial code of conduct. The Education Act, school 
boards policies and procedures, and school-level codes of conduct form the "three political and administrative layers [that] guide school personnel" when responding to student misconduct (Raby, 2012, p. 6).

The Act differentiates between suspensions and expulsions. Suspensions can result in being excluded from school for up to 20 days; expulsions can result in the complete exclusion of a student from a specific school or from all of the schools in a given school board, though the school board still has an obligation to provide the student an education through other means (Policy/Program Memorandum No. 142 - School Board Programs for Expelled Students). When a student is alleged to have committed an act that could lead to suspension or expulsion, their parents are provided a notice of the (discretionary) suspension or, in more egregious matters, notice of the (mandatory) suspension pending potential expulsion. In cases of a suspension only, the parent has 10 days to submit an appeal to the school board. In the case of a suspension pending potential expulsion, the appeal process must await an investigation by the school principal, who within 20 days of the initial suspension will recommend to the school board whether or not expulsion is warranted in the circumstances. If expulsion is recommended, the board of trustees or a committee thereof will hold a hearing to determine if the expulsion will in fact be imposed. If no expulsion is recommended, the suspension that was imposed during the investigation can be appealed using the usual suspension appeal process. Only expulsions can be further appealed to the provincial Child and Family Services Review Board.

Activities leading to possible suspension require principals to use their discretion as to whether or not a suspension is necessary in the circumstances. Such activities include threats, swearing, possession of alcohol or drugs, vandalism, bullying, and "any other activity that is an activity for which a principal may suspend a pupil under a policy of the board" (Education Act, s. 306). In some school boards, this includes the rather vague ground of "conduct injurious to the moral tone of the school" (for example, Toronto Catholic District School Board, 2016). In more egregious cases - possession or use of weapons, assault, trafficking, robbery, repeated bullying, activities on the discretionary suspension list when "motivated by bias, prejudice or hate" based on a protected ground under the Ontario Human Rights Code (Education Act, s. 310), and any other activity set out in board policy for which a principal must suspend a student - a principal has no discretion. The student must be suspended if the principal believes the student may have committed such an infraction and within 20 days investigate and make a recommendation to the 
school board whether the student should be expelled. As Jeffery Wilson (2011), a legal practitioner specializing in child and youth law, has noted,

It is not clear what evidentiary standard is set by the phrase 'suspend the pupil if he or she believes that ...' [...] Unlike the police, the principal is not required to believe that the pupil has committed a mandatory expulsion infraction, but that he or she may have done so. (p. 257)

A student who faces a mandatory suspension pending potential expulsion, but is ultimately exonerated, could therefore lose 20 school days or more based on a mistaken belief. This is "a potentially significant cost to [the student's] educational progress and their relationship with the school and their peers" (Wilson, 1994, §8.39.4). It is difficult to see how such an outcome is in the child's best interests. Indeed, many authors have noted that exclusionary discipline practices in general show little benefit and can in fact be detrimental to student achievement (Covell, 2020; Lundy \& O’Lynn, 2019; Howe \& Covell, 2013).

When imposing discretionary suspensions, conducting investigations following mandatory suspension, or considering an expulsion recommendation, the respective decisionmakers - the principal in the first two instances and the school board in the third - must take into consideration mitigating and other factors (Education Act). Mitigating factors "operate to reduce either the seriousness of the activity or the appropriateness of the discipline in light of the student's history and/or the particular circumstances surrounding the activity" (Scott, 2019, p. 3). These mitigating factors include the student's ability to understand the foreseeable consequences of their behaviour; the student's age and history, including history of progressive discipline; whether the behaviour in questions is related to a disability or to harassment contrary to the Human Rights Code; and, the effect of the disciplinary measures on the student's ongoing education (Ontario Regulation 472/07 - Behaviour, Discipline and Safety of Pupils, ss. 2, 3). Failure to take into consideration the interplay of mitigating and other factors can lead to disproportionate disciplinary measures against marginalized and economically disadvantaged students (Howe \& Covell, 2013). Unfortunately, there are no guidelines that set out how to gather the information needed to assess these factors.

In both suspension appeals and expulsion proceedings, the affected student may attend the hearing and make a statement (Education Act). The affected student is not a party to the proceeding unless they have turned 18 years old or are 16 or 17 years old and have withdrawn 
from parental control. Otherwise, only the parent or guardian may initiate an appeal and be a formal party to suspension appeals and expulsion proceedings. The same applies to appeals of expulsions to the Child and Family Services Review Board (Scott, 2019). School board policies may expand the scope of parties in suspension and expulsion proceedings to grant standing to students (Education Act), and at least one does (Simcoe County District School Board, 2019). This means that the participation rights of affected students depend entirely on each school board's policies and procedures, making students' right to participation a patchwork: the same child might have different rights depending on whether they attend an English or French, public or Catholic school board (Covell, Howe, \& Blokhuis, 2018; Wilson, 1994). For example, a student attending an English public school in Barrie, Ontario has the right to appeal their suspension or participate in their school board-level expulsion hearing as a party (Simcoe County District School Board, 2019), whereas a student attending an English Catholic school (Simcoe Muskoka Catholic District School Board, 2015), French public school (Conseil scolaire Viamonde, 2018), or French Catholic school (Conseil scolaire catholique MonAvenir, 2019) in the same city does not.

At the level of the Child and Family Services Review Board, which hears appeals of expulsions under the Education Act as well as certain matters under the Child, Youth and Family Services Act, 2017, an expelled student may provide a statement or may testify as a witness at an expulsion appeal hearing but cannot initiate the appeal or cross-examine other witnesses regardless of the students' party status at the school board level, given the limitation on party status in the Education Act (Scott, 2019). A student in a school board that allows them to challenge a potential expulsion in the first instance loses that right on appeal to a provincial tribunal, undermining the Convention's guarantees of participation in all matters that affect a child.

The "values underlying the duty of procedural fairness" (Baker, para 28) mean providing students with direct participation rights in school discipline processes under the Education Act, thereby also respecting the Convention. Indeed, "[i]t is hard to conceive of a more elementary deficiency in procedural fairness than the lack of party status for the subject whose rights are most affected" (Wilson, 2011, p. 265). The lack of a specific grant of standing for children in the education system, along with the lack of any mechanisms to provide for representation other than their parent or guardian, can lead to cases of students who are otherwise responsible for their 
own schooling being unable to participate in school discipline proceedings that affect them directly. Many students who face suspension and expulsion cannot rely on their parents or guardians to advocate for them or to appeal decisions once made (Hussain, 2015; Milne \& Aurini, 2015). This lack of parental involvement in schooling has been attributed to financial pressures, illness, employment pressures, cultural differences, and intergenerational traumas within the family setting (Hussain, 2015). In the next section, I discuss problems of relying solely on parental rights in matters of school discipline as well as procedural issues even if children were to have participation rights in school discipline.

\section{Problems of Parental Rights and Procedure}

Covell, Howe, \& McGillivray argue that "[t]he child's right to education as well as to information and participation in decision making effectively is trumped by false notions of parental rights" (2017, p. 305). Justifications for this gap in legal rights can be found in paternalistic and proprietary views of children as well as in developmental and protectionist views of children as immature (Godwin, 2015; Appell, 2013). In Canadian law, the child's lack of legal standing independent from the adults in their lives stems from legal principles that have evolved out of the common law (Wilson 2011). Laws affecting children and youth "find their political validity in what is deemed to be in children's 'best interests' as opposed to what children themselves think" (p. 8). As a result, the law affecting children and youth is often a reflection of the interests of those writing and applying the law and of adult biases and assumptions with respect to "best interests." This idea of parents working in their children's best interests arises out of the trust-based relationship that is supposed to exist between parents and their children, with parents having duties to protect their child's rights and act against those who might interfere with these rights (Covell, Howe, \& McGillivray, 2017; McGillivray, 2011). What happens if parents cannot uphold their end of the bargain in matters of school discipline?

The Convention's participation provisions do not explicitly state that children should be able to advocate for themselves or be given standing in all matters that concern them (Daly, 2018; Appell, 2013). To Daly, this means that "it is entirely open to adults to decide when a child is "capable of forming his or her own views"” (2018, p. 47). Indeed, the Convention "itself fully embraces the developmental, subordinated, categorical child" despite "recognizing children not as property but as human beings who should have identities, procedural rights, and moral rights" 
(Appell, 2013, p. 732-733). This "adoption of the development thesis defines children by their limitations and potential, eliding their identities as agents, subjects, and individuals" (p. 734).

Godwin (2015) challenges the robust conception of parental rights in United States law that recognizes the interests of children almost exclusively through their parents, finding this to be "fundamentally incompatible with a belief in the equality of persons as possessors of morally equal interests, worth, and standing" (p. 36). For Godwin,

the recognition of parental interests in children comes at the expense of recognizing children's own interests in themselves. This entails according[ly] a diminished recognition of children's interests compared with the interests of other people. Adults' interests in themselves are treated as whole and without encumbrances, but children's interests in themselves are considered in relation to their parents' competing interests in them. (p. 37)

While there may be good reasons for legally recognizing the caretaking obligations of parents toward their children, those reasons do not mean "that because individuals are not able to function independently and autonomously that they cannot have independent rights separate from their caregivers" (Godwin, 2015, p. 60-61). Discounting children's agency in such a way is not about children's inability to express themselves and make choices (Godwin, 2015); it is a choice that society, through its courts and lawmakers, has made to categorically deny children their rights as individuals (Appell, 2013). This choice does not hold up to scrutiny in light of studies of children's views with respect to school discipline specifically and fairness generally. Nor does it align with what has been agreed to in the Convention.

Studies produced over the past two decades show that students in Ontario and elsewhere “are concerned with fairness" (Raby, 2012, p. 123) when it comes to school discipline matters and in school life generally (Hussain, 2015; Raby, 2012; Mosher, 2008; Rudduck \& Flutter, 2004). Consistent themes emerge from these studies showing that students consider fairness to be about balancing power differentials through access to information, gaining agency through participation in decision-making, and being sensitive to context as a matter of respect for students as individuals living in the world. For example, Janet Mosher (2008), a Canadian legal scholar, found that for racialized students in a Toronto neighbourhood, access to justice requires understanding, engagement with the reality of others, transparency regarding both the content of the rules/laws and how authority is exercised 
in relation to those rules, the opportunity to participate (to speak, to be heard), and the opportunity to learn (including through mistakes). (p. 850)

Similarly, interviews conducted in the United Kingdom by Rudduck \& Flutter (2004) identify three principles that "directly affect the student's 'sense of self-as-learner"” as being respect, fairness "to all students irrespective of their class, gender, ethnicity or academic status," and autonomy (p. 135). Mosher also described the "language of justice" spoken by youth as one of “[u]nderstanding, mutual respect, and second chances" (2008, p. 814). The perspectives demonstrate that students are capable of understanding the processes that currently exclude them in Ontario. Moreover, the students' comments echo the Convention's statements on participation, best interests, and dignity in school discipline.

This language is not just used by children. Studies among adults who have interacted with state authorities found respect to be a key aspect of fairness. Tyler (1988) conducted and reviewed multiple studies with respect to what fairness means in this context. He opined that procedural concerns are paramount in subjective assessments of fairness and identified several factors affecting subjective feelings of fairness, not least of which is participation in decisionmaking. Reflecting legal principles of procedural fairness, Tyler describes the following as elements of "procedural justice":

[that] decision making is viewed as being neutral, consistent, rule-based, and without bias; that people are treated with dignity and respect and their rights are acknowledged; and that they have an opportunity to participate in the situation by explaining their perspective and indicating their views about how problems should be resolved. (p. 300301)

Tyler later distilled his findings into "four key procedural justice principles: voice, neutrality, respect, and trust" (2007, p. 30). Voice relates to being able to meaningfully tell your story. Neutrality is about consistency and transparency. Respect is about being taken seriously and includes being provided appropriate information and assistance. Finally, trust is about "sincerity and caring." On the interplay of these principles, Tyler found that "voice ... shapes neutrality, trust and respect" (p. 30-31).

The views of children who have interacted with school discipline processes canvassed above map rather neatly onto the four procedural justice principles proposed by Tyler: students want to be treated respectfully by trusted educators who apply the rules consistently and give 
them the chance to be heard. Indeed, Tyler and Trinkner (2018) found that fairness in school is about teachers showing they care by respecting students and communicating with them. It is also about consistently and transparently applying rules and explaining decisions. Indeed, "the impact of school rules is very much related to their perceived fairness both along decision-making and treatment dimensions" (p. 182-183). Students therefore view a fair process as being necessary to ensuring a fair outcome in school discipline.

In light of the evidence that the views of children are generally consistent with those of adults in analogous circumstances (Tyler 2007; Tyler \& Trinkner 2018), concerns with respect to the capacity of children to express themselves are not well founded. The fact that children assess fairness in ways similar to adults is consistent with studies showing that children are "able to evaluate the fairness of activities" (Weisz, Wingrove, \& Faith-Slaker, 2007, p. 36). Young children "can think critically about the fairness of law" and even preschool children can understand the concepts of fairness and rights when they are modelled "in a rights-respecting teaching environment" (Howe \& Covell, 2013, p. 221). The capacity of children to understand and to participate in decision-making has therefore been underestimated (Erickson, 2001).

Moreover, when children say they want to participate and be heard, they want to do so directly, without an intermediary who may misinterpret their thoughts and feelings (Covell, Howe, \& Blokhuis, 2018; Daly 2018). They also want to be certain that their views and opinions are taken seriously. Excluding children and youth from decision-making only serves to reinforce feelings of alienation and powerlessness (Hotrum \& Dasmohapatra, 2010). In the school discipline context, the lack of direct participation rights for students in school discipline undermines students' faith in the process (Hussain 2015; Mosher 2008). Students' feelings of powerlessness in the face of disciplinary action (Hussain, 2015) are exacerbated by the “experience of being silenced" (Mosher et al, 2008, p. 840). For students who may already be disadvantaged due to race, poverty, and family status, a lack of voice in school decision-making can perpetuate preexisting suspicions of social institutions and feelings of lack of agency (Raby, 2012).

Participation rights alone are not sufficient, however. Getting in front of a decision-maker is only meaningful if the child's right to be heard is respected and acknowledged and they are given sufficient information with respect to the proceedings (Justice for Children and Youth, 2013). The key elements of participation under the Convention, and in terms of procedural 
fairness generally, relate to receiving sufficient information, having the opportunity to be heard, and having one's individual circumstances considered by the decision-maker prior to a decision being made. As discussed above, students themselves have identified problems of access to relevant information, ability to be heard, and having individual circumstances considered in school discipline proceedings (Mosher, 2008).

The school discipline provisions of the Education Act fulfil at best one of these elements given the requirement to consider mitigating factors. There is no requirement to consider the views of the student in assessing these factors and, with respect to information and being heard, little is provided for beyond a written notice of suspension and a possibility of giving a statement (Education Act). Moreover, discipline policies and procedures can be long, complex, and highly formalized: for example, Simcoe Muskoka Catholic District School Board’s discipline policy and procedure (2015) is 79 pages long. As such, even if a student is given access to all the relevant procedural information, it may be of little assistance in encouraging meaningful participation - that is, participation that fully respects the student's dignity and capacity - in disciplinary proceedings. Ultimately, and contrary to the Convention, in the current school discipline context "there is little room ... to recognize that young people can and should have formal avenues to challenge school rules, or that they may have legitimate reasons to do so" (Raby, 2012, p. 105).

Even where participation is part of the process, students may fear reprisal in case their comments are "seen as an attempt to undermine adult authority rather than their fundamental human right" (Covell, Howe, \& Blokhuis, 2018, p. 133). Here again, we see the Convention's promise of dignity in school discipline not being met. Many of the students in Hussain's study "felt as if the school safety policies were happening to them as opposed to feeling as if the policies were in their best interest" (2015, p. 229), and Mosher found that students held similar beliefs in their study: for students facing discipline, "law is simply what the powerful authority figures in their lives ... command at any given moment" (2008, p. 812). Students' deep dissatisfaction with the application of discipline policies has been attributed to a lack of awareness of how school discipline systems work (Hussein, 2015). Even though students had had interactions with various apparatuses of the state, they "had little idea of the governing legal norms or of their rights (substantive or procedural)" nor "what the authority figures present in their lives were legally permitted to do" (Mosher et al, 2008, p. 836). In most cases, this lack of 
information led to a lack of engagement with available review and appeal processes (Mosher, 2008).

In the context of school discipline, that children understand fairness and are capable of expressing this understanding means that they should be given the opportunity to participate as individual rights-holders at all stages of disciplinary proceedings. However, without adequate information and appropriate procedures, the right to participate in a school discipline proceedings rings hollow. I therefore now conclude with ways in which more meaningful participation could be facilitated in school discipline in Ontario.

\section{Access to Justice for Self-Represented Children in School Discipline}

The Supreme Court of Canada in Pintea $v$ Johns endorsed the notion that judges have a duty to ensure that self-represented parties are aware of relevant procedures and of the potential impact of a self-represented party's procedural choices on a proceeding (Scarrow \& Macfarlane, 2018). The Ontario Court of Justice expanded on this idea in Catholic Children's Aid Society Toronto $v C G$, where the court found that access to justice for self-represented parties means that court processes need to be as transparent and accessible as possible and that procedural and evidentiary rules should not be used to hinder a self-represented party's interest (Scarrow \& Macfarlane, 2018). If self-represented adults are supposed be accommodated in legal proceedings, then there is little reason not do so for children who seek to advance their own interests.

Children tell us that voice, neutrality, respect, and trust matter to them in school discipline decision-making. They want to participate in decisions that affect them, benefit from transparent and consistent procedures, have access to relevant information and be taken seriously, and feel supported throughout the process. In the school discipline context in Ontario, this would mean centring students in the design of discipline processes, making information about those processes accessible to all students in formats they understand, ensuring all educators and officials have sufficient and relevant training to facilitate students' participation, and, of course, guaranteeing students' participation rights in all schools across the province by enshrining those rights in the Education Act.

Giving students standing in school discipline under Ontario's Education Act - a right students in the Province of British Columbia already enjoy (Schools Act, s 11(2)) - would allow students to at least get their foot in the door to challenging a disciplinary decision, including the 
right to appeal expulsions directly to the Child and Family Services Review Board. In so doing, the dignity and autonomy of students would be respected. In addition, proper structures and procedures for child participation need to be implemented and children need to be aware of their rights (Covell, Howe, \& Blokhuis, 2018), as “[c]hildren cannot be involved freely in proceedings if those processes are totally alienating to them" (Daly, 2018, p. 52). Clear and consistent information about participation rights and discipline procedures could go a long way to levelling the disciplinary playing field for students (Tyler, 2007). Such information needs to be in a format that students will understand, and procedures need to be crafted so as to invite students to express themselves in ways that work for them, not necessarily using methods designed for adults (Paré, 2010, 2015; Daly, 2018). This again speaks to ensuring students' dignity in school discipline. Finally, educators need to receive adequate and regular training about not only student discipline procedures, including how mitigating and other factors are assessed, but also on how the procedures interact with children's rights in schools (Collins \& Paré, 2016; Howe \& Covell, 2013; Raby, 2012). While some work has been done with respect to child-friendly practices for courts (for example, Council of Europe, 2011), further study into specific ways that school discipline processes could be made more child-friendly in the Ontario or Canadian context would provide decision-makers models that could be implemented in relevant policies and legislation.

However, operationalizing children's right to participation can be difficult. A study of participatory projects in Ontario schools showed that school staff may be reticent to fully embrace student participation in decision-making (Hostrum \& Dasmohapatra, 2010). This resistance appears to be correlated with a lack of knowledge and training among educators, leading to a "lack of infrastructure to institutionalize youth engagement and the role of students as stakeholders in reform" (p. 16). These findings reflect similar findings in the child protection context (Covell, Howe, \& Blokhuis, 2018) and echo students' perceptions of school officials' understanding and application of rules in the school discipline context (Hussain, 2015; Mosher, 2008). Given the apparent reluctance of adults to share power with young people (Covell, Howe, \& Blokhuis, 2018), bringing children into decision making processes requires rethinking power relations in schools (John, 2001), something legislators tend not be interested in doing (Covell, Howe, \& McGillivray, 2017). More broadly, Daly (2018) challenges the sufficiency of "being heard" in proceedings with respect to a child's best interests and argues for a system based in children's autonomy. She proposes a "children's autonomy principle" that would empower 
children to choose how they are involved in processes and, in appropriate circumstances, choose the outcome unless that choice is likely to lead to significant harm. Similarly, Appell (2013) proposes that the United States adopt a "children's participation amendment" to its constitution that would presume competency in children and place the burden of accommodating children's needs on "those who would limit children's freedom and autonomy" (p. 751). These proposals, which presume a child's capacity and put the onus on the state to prove otherwise, align with the model of human rights set out in the Convention (Covell, Howe, \& McGillivray, 2017).

As the UN Committee on the Rights of the Child has noted, "respect for the rights within education is fundamental to the realization of the right to education" (2009, para 105). Practices of student-involved decision-making have been shown to increase respect for rights among students and between students and school officials (Howe \& Covell, 2013). In schools with child rights-focused practices, there was greater cooperation, greater sensitivity to the needs of students with disabilities, and decreased recourse to formal disciplinary measures such as suspension and expulsion (Covell, Howe, \& McGillivray, 2017). Participation, then, is not just about implementing formal recognition in law but also about ensuring school practices will be informed by children's participation (Collins \& Paré, 2016). By respecting children as individual rights-holders in schools in Ontario and elsewhere, we would not only better meet our obligations under the Convention but also find ways to make schools better for all. 


\section{References}

Aiken, S., \& Scott, S. (2000). Baker v. Canada (Minister of Citizenship and Immigration) and the Rights of Children. Journal of Law \& Social Policy, 15, 211-254. Retrieved from https://digitalcommons.osgoode.yorku.ca/jlsp/vol15/iss 1/7

Appell, A.R. (2013). Accommodating Childhood. Cardozo Journal of Law \& Gender, 19, 715779. Retrieved from https://ssrn.com/abstract=2295061

Baker v. Canada (Minister of Citizenship and Immigration), [1999] 2 SCR 817, 1999 CanLII 699 (SCC).

Bala, N. \& Houston, C. (2015). Article 12 of the Convention on the Rights of the Child and Children's Participatory Rights in Canada. Minister of Justice and Attorney General of Canada. Retrieved from https://www.justice.gc.ca/eng/rp-pr/otherautre/article12/Article12-eng.pdf

Cameron, A., \& Daly, P. (2013). Furthering Substantive Equality Through Administrative Law: Charter Values in Education. Supreme Court Law Review (2d), 63, 169-204.

Collins, T.M., \& Paré, M. (2016). A Child Rights-Based Approach to Anti-Violence Efforts in Schools. The International Journal of Children's Rights, 24(4), 764-802. https://doi.org/10.1163/15718182-02404005

Conseil scolaire catholique MonAvenir. (2019). ÉLV.9: Mesures disciplinaires, suspension et renvoi d'un(e) élève. Retrieved from https://www.cscmonavenir.ca/publications/politiques/ELV.9.pdf

Conseil scolaire Viamonde. (2018). Directive administrative 3,32: Stratégie pour la sécurité dans les écoles. Retrieved from https://csviamonde.ca/fileadmin/viamonde/Politiques_du_conseil/Education_et_ecoles/ EetE_D_administratives/3_32_Securite_dans_les_ecoles_dir_adm.pdf

Council of Europe. (2011). Guidelines of the Committee of Ministers of the Council of Europe on Child-friendly Justice. Adopted by the Committee of Ministers of the Council of Europe on 17 November 2010. Strasbourg, France. Council of Europe Publishing

Covell, K., Howe R.B., \& Blokhuis, J.C. (2018). The Challenge of Children's Rights for Canada, 2nd ed. Waterloo, ON: WLU Press. 
Covell, K., Howe R.B., \& McGillivray, A. (2017). Implementing Children's Education Rights in Schools. In M.D. Ruck, M. Peterson-Badali, \& M. Freeman (Eds). Handbook of Children's Rights: Global and Multidisciplinary Perspectives (296-311). New York, NY: Routledge.

Daly, A. (2018). Children, Autonomy and the Courts: Beyond the Right to be Heard. Leiden, Netherlands: Koninklijke Brill.

Eaton v. Brant County Board of Education, [1997] 1 S.C.R. 241.

Erickson, M.F. (2001). Status and Prospects: Concluding perspectives. In S. Hart, C. PriceCohen, M.F. Erickson, \& M.G. Flekkoy (Eds). Children's Rights in Education (217229). London, England: Jessica Kingsley Publishers.

Godwin, S. (2015). Against Parental Rights. Columbia Human Rights Law Review, 47, 1-83. Retrieved from: https://ssrn.com/abstract=2702919

Government of Ontario. (2007). Behaviour, Discipline and Safety of Pupils. O Reg 472/07. Government of Ontario. (2012). Policy/Program Memorandum No. 142 - School Board Programs for Expelled Students. Retrieved from http://www.edu.gov.on.ca/extra/eng/ppm/142.pdf

Government of Ontario. (2017, August 16). The Anishinabek Education System: An Overview. Retrieved from https://news.ontario.ca/en/backgrounder/45893/the-anishinabekeducation-system-an-overview

Government of Ontario. (2018). Policy/Program Memorandum No. 145 - Progressive Discipline and Promoting Positive Student Behaviour. Retrieved from http://www.edu.gov.on.ca/extra/eng/ppm/145.pdf

Grover, S.C. (2008). The Child's Right to Legal Standing. Markham, ON: LexisNexis. Hill, M.G. (2013). Step by Step to a Safer School, 2nd ed. Markham, ON: LexisNexis. Hotrum, A. \& Dasmohapatra, S. (2010). Finding a Voice in School 2010: A Participatory Action Project in Ontario's Education System. Office of Provincial Advocate for Children and Youth.

Howe, R.B. \& Covell, K. (2013). Education in the Best Interests of the Child: A Children's Rights Perspective on Closing the Achievement Gap. Toronto, ON: University of Toronto Press. 
Hussain, S.A. (2015). The Effects of Ontario’s Safe Schools Policy on Racialized Students (2000-2013). PhD Thesis. Kingston, ON: Queen’s University. Retrieved from http://hdl.handle.net/1974/13729

John, M. (1996). Voicing: Research and Practice with the 'Silenced.' In M. John (Ed.). Children in Charge: The Child's Right to a Fair Hearing (3-24). London, England: Jessica Kingsley Publishers.

Justice for Children and Youth. (2013). Children's Right to be Heard in Canadian Judicial and Administrative Proceedings. Retrieved from: http://jfcy.org/wpcontent/uploads/2013/10/UNDiscussionPaper.pdf

Klein, R. (2013). We Want Our Say: Children as active participants in their education. Staffordshire, England: Trentham Books.

Kränzl-Nagl, R. \& Zartler, U. (2010). Children's participation in school and community: European perspectives. In B. Percy-Smith \& N. Thomas (Eds.). A Handbook of Children and Young People's Participation: Perspectives from theory and practice (164-173). New York, NY: Routledge.

Legislative Assembly of British Columbia. (1996). School Act. RSBC 1996, c 412.

Legislative Assembly of Ontario. (1990). Education Act. RSO 1990, c E.2.

Legislative Assembly of Ontario. (2017). Child, Youth and Family Services Act. SO 2017, c 27, Sched 1.

Lundy, L., \& O’Lynn, P. (2019). The Education Rights of Children. In U. Kilkelly \& T. Liefaard, International Human Rights of Children, 259-276. Singapore: Springer.

Macfarlane, J., \& Scarrow, K. (2018). Pintea v Johns: 18 Months Later. Retrieved from https://scholar.uwindsor.ca/lawpub/83

Mason, S.P. \& Price-Cohen, C. (2001). Children's Rights in Education. In S. Hart, C. PriceCohen, M.F. Erickson, \& M.G. Flekkoy (Eds). Children's Rights in Education (15-36). London, England: Jessica Kingsley Publishers.

McGillivray, A. (2011). Children's Rights, Paternal Power and Fiduciary Duty: From Roman Law to the Supreme Court of Canada. International Journal of Children's Rights, 19(1), 21-54. 
Milne, E. \& Aurini, J. (2015). A Tale of Two Policies: The Case of School Discipline in an Ontario School Board. Canadian Journal of Educational Administration and Policy, $183,30-43$.

Mosher, J.E. (2008). Lessons in Access to Justice: Racialized Youths in Ontario's Safe Schools. Osgoode Hall Law Journal, 46, 807-851. Retrieved from https://digitalcommons.osgoode.yorku.ca/ohlj/vol46/iss4/4/

Paré, M. (2010). La participation des personnes handicapées dans les décisions qui les concernent : L'exemple de l'éducation. Law Commission of Ontario. Retrieved from https://www.lco-cdo.org/en/our-current-projects/the-law-and-persons-withdisabilities/disabilities-call-for-papers-january-2010/commissioned-papers-the-law-andpersons-with-disabilities/the-participation-of-persons-with-disabilities-in-the-decisionsthat-concern-them-the-example-of-education/

Paré, M. (2015). Inclusion and Participation in Special Education Processes in Ontario, Canada. In T. Gal \& B.F. Duramy (Eds.). International Perspectives and Empirical Findings on Child Participation: From Social Exclusion to Child-Inclusive Policies (37-57).

Oxford, England: Oxford University Press.

Paré, M. (2017). Children's Rights Are Human Rights and Why Canadian Implementation Lags Behind. Canadian Journal of Children's Rights, 4(1), 24-47.

Paré, M. \& Collins, T. (2016). Government Efforts to Address Bullying in Canada: Any Place for Children's Rights? Journal of Law \& Social Policy, 25, 54-77. Retrieved from https://digitalcommons.osgoode.yorku.ca/jlsp/vol25/iss 1/3

Raby, R. (2012). School Rules: Obedience, Discipline, and Elusive Democracy. Toronto, ON: University of Toronto Press.

Reid, L. (2017). Invented Power: An Analysis of the Exclusion Clause in Ontario's Education Act. In C. Spindler (Ed.). CAPSLE 2016: Bright Lights on Emerging Issues in Education Law. Canadian Association for the Practical Study of Law in Education.

Rudduck, J. \& Flutter, J. (2004). How To Improve Your School: Giving Pupils A Voice. London, England: Continuum.

Scott, J. (2019). Expulsion Appeals: Framework for the Legal Analysis. Ontario Bar Association Institute 2019 Education Law Section Program. Toronto, ON: Ontario Bar Association. 
Simcoe County District School Board. (2019). Administrative Procedures Memorandum A7635

- Student Discipline Procedures. Retrieved from

https://www.scdsb.on.ca/common/pages/DisplayFile.aspx?itemId=916955

Simcoe Muskoka Catholic District School Board. (2015). Policy LE-16: Student Discipline.

Retrieved from

https://www.smcdsb.on.ca/common/pages/DisplayFile.aspx?itemId=36119718

Sitch, G. \& McCoubrey, S. (2001-2002) Stay in Your Seat: The Impact of Judicial

Subordination of Students' Rights on Effective Rights Education. Education \& Law Journal, 11, 173-202.

Statistics Canada. (2016). Census Profile, 2016 Census: Ontario [Province] and Canada [Country]. Retrieved from https://www12.statcan.gc.ca/census-recensement/2016/dp$\mathrm{pd} /$ prof/index.cfm?Lang=E

Toronto Catholic District School Board. (2016). S.S. 01 - Suspension and Expulsion Policy (Consolidated). Retrieved from https://www.tcdsb.org/Board/Policies/Documents/SS01.pdf

Tyler, T.R. (1988). What is Procedural Justice?: Criteria used by Citizens to Assess the Fairness of Legal Procedures. Law \& Society Review, 22, 103-136. DOI: 10.2307/3053563

Tyler, T.R. (2007). Procedural Justice and the Courts. (2007) Court Review, 44, 26-31. Retrieved from http://digitalcommons.unl.edu/ajacourtreview/217

Tyler, T.R. \& Trinkner, R. (2017). Why Children Follow Rules: Legal Socialization and the Development of Legitimacy. Oxford, England: Oxford University Press.

United Nations. (1989). Convention on the Rights of the Child. November 20, 1989, 1577 U.N.T.S. 3.

United Nations Committee on the Rights of the Child. (2001). General Comment No. 1. Article 29(1): The Aims of Education. CRC/GC/2001/1.

United Nations Committee on the Rights of the Child. (2009). General Comment No. 12. The right of the child to be heard. $\mathrm{CRC} / \mathrm{C} / \mathrm{GC} / 12$.

Verheyde, M. (2006). A Commentary on the United Nations Convention on the Rights of the Child, Article 28: The Right to Education. Leiden, Netherlands \& Boston, MA: Brill Nijhoff. 
Weisz, V., Wingrove, T., \& Faith-Slaker, A. (2007). Children and Procedural Justice. Court Review, 44, 36-43. Retrieved from https://digitalcommons.unl.edu/ajacourtreview/216

Wilson, J. (1994). Wilson on Children and the Law, 3rd edn. Markham, ON: Butterworths.

Wilson, J. (2011). The law's treatment of youth and children. Markham, ON: LexisNexis Canada.

Zuker, M. \& Kirwin, L.M. (2015). Children's law handbook, 3rd ed. Toronto, ON: Carswell. 